\title{
Risks assessment in terms of OHS for critical power infrastructures in context of industrial safety
}

\author{
Dragos Pasculescu ${ }^{*}$, Nicolae Daniel Fita ${ }^{1}$,Emilia Grigorie $^{1}$, Florin Gabriel Popescu ${ }^{1}$, and \\ Alina Daniela Handra ${ }^{1}$ \\ ${ }^{1}$ University of Petrosani, Romania
}

\begin{abstract}
The aim of occupational health and safety in the context of industrial safety is to provide the national industry with a proper operation state, an ergonomic, optimal and healthy work environment, safe workers and workplaces, safety of industrial processes, to limit and mitigate any unforeseen situation generated by events which might negatively affect the occupational health and safety level. The current paper approaches the risk assessment in terms of occupational health and safety within a cross-border $400 / 220 \mathrm{kV}$ power substation interconnected to the European power grid, identified and assigned as European critical infrastructure. The assessment is carried out using the INCDPM Bucharest method, in order to establish the risk/safety levels in a quantitative manner, based on a systemic analysis and on the assessment of risks of accidents and professional diseases. The application of the method ends in a workplace assessment sheet which comprises the global risk level of the power substation and which sets the grounds for the plan for preventing accidents and professional diseases within the analysed power substation.
\end{abstract}

\section{Description of the INCDPM Bucharest method for risk assessment in terms of OHS}

The method developed by National Research and Development Institute of Occupational Safety "Alexandru Darabont" - INCDPM Bucharest, aims to determine the quantitative level of risk/safety for a workplace, sector, section or company, based on a systemic analysis and assessment of risks of injury and occupational disease, in terms of Occupational Health and Safety - OHS. The application of the method is finalised with a summary document Assessment Sheet of Workplace, which includes the global risk level of the workplace. The developed assessment sheet of the workplace is the basis of the program for the prevention of accidents and occupational diseases for the workplace, sector, section or company analysis. The essence of the method is to identify all risk factors in the system analysis (workplace) on the basis of pre-established control lists and to quantify the risk dimension on the basis of the combination of the severity and frequency of the maximum foreseeable consequence. The level of security for a workplace shall be inversely

*Corresponding author: pdragos 74@yahoo.com 
proportional to the level of risk. The method comprises the following mandatory steps $[1,2$, 8, 9]:

1) The definition of the system to be analysis (workplace);

2) The identification of risk factors from the system;

3) Assessment of risks of injury and occupational disease;

4) Risk prioritization and prevention priorities;

5) Proposal for prevention measures.

\section{Working tools:}

1) List for identifying risk factors (performer, work environment, work load, means of production);

2) List of possible consequences of the action of risk factors on the human body (possible consequences, location of consequences);

3) Quotation scale of severity and probability of consequences (severity class/consequences - severity of consequences, classes of probability/events probability of consequences);

4) Risk assessment scale (severity class, probability class);

5) Scale for the assignment of risk levels, respectively safety levels (levels of risk safety levels);

6) Workplace assessment sheet - summary document (general information, actual assessment);

7) Proposed measures sheet (record-keeping and follow-up of proposed measures).

The global risk level (Nr) per workplace shall be calculated as a weighted average of the risk levels established for the identified risk factors. In order for the result obtained to reflect as accurately as possible the reality, the risk factor ranking, which is equal to the level of risk, shall be used as a weighting element. In this way, the highest risk factor will also be the highest ranking. Thus, it is eliminated the possibility for the cross-compensation effect, involved by any statistical average, to mask the presence of the highest-risk factor.

The formula for calculating the global risk level is the following:

$$
N_{r}=\frac{\sum_{i=1}^{n} r_{i} \cdot R_{i}}{\sum_{i=1}^{n} r_{i}}
$$

where:

$\mathrm{N}_{\mathrm{r}}$ - the level of global risk in the workplace;

$\mathrm{r}_{\mathrm{i}}$ - risk factor ranking ,i”;

$\mathrm{R}_{\mathrm{i}}$ - level of risk for the risk factor , $\mathrm{i}$ ";

$\mathrm{n}$ - number of risk factors identified at the workplace.

The level of security (Ns) at workplace is identified on the risk/security level mapping scale, built on the opposite proportionality of risk and security levels. Both the global risk level and the safety level are recorded in the workplace sheet. In the case of macro-systems assessment (sector, section, company), the weighted mean of the average safety levels determined for each workplace analysed in the macro-system component (similar workplace are considered as a single workplace) has to be calculated so that to obtain the global level of safety at work for the workshop/section/sector or enterprise under investigation - Ns: 


$$
N_{g}=\frac{\sum_{p=1}^{n} r_{p} \cdot N_{s p}}{\sum_{p=1}^{n} r_{p}}
$$

where:

$r_{p}$ - the workplace ranking "p" (equal to the risk level of the workplace);

$\mathrm{n}$ - number of workplaces analysed;

$\mathrm{N}_{\mathrm{sp}}$ - average workplace safety level "p".

\section{The aim of critical power infrastructures in context of industrial safety}

For the purpose of industrial safety and societal security, the state must provide a series of facilities for people and companies, such as: access to drinking water and sewage, various fuels, natural gas, electricity, heat, resources, raw materials, etc., so that the economic development to be in continuous progress and in a secure environment. These very important facilities are provided by certain infrastructures, which fall into three main categories $[3,10]$ :

- normal infrastructures - a framework structure that ensures the construction and operation of a system;

- $\quad$ special infrastructures - with a consistent role in the operation of systems and processes and a high degree of stability and security in all the mechanisms of economic and social life of regional interest;

- $\quad$ critical infrastructures - are usually determinants of the instability, security and safety of systems and processes, with an important role in the development of economic-social, political and military processes.

The vulnerability of these infrastructures generates a number of risks and threats to them, thereby endangering industry and societal life, creating dysfunctionalities and causing extreme damage to the economy and society. Critical infrastructure is thus becoming indispensable for industry and society, without which the state and its mechanisms cannot operate and ensure industrial safety and societal well-being, and their protection and/or security becomes a major national and European objective, prompting the representatives of the member states of the EU to take action towards the identification, management and assessment of any risk or threat that could jeopardize the well-being of European citizens. Disruption or destruction of a critical infrastructure may have the following consequences on national and European security:

- $\quad$ societal insecurity - population affected by lack of facilities;

- industrial insecurity - industrial entities affected by the lack of facilities and stagnation of production;

- economic insecurity - economic loss;

- medical insecurity - population affected by a lack of public health care system;

- ecological insecurity - loss or destruction of the environment, etc.

As the whole industry-economic environment depends on the facilities of the critical energy infrastructures (ultra-high-voltage and very high-voltage power substations and overhead lines - OHL), it makes the issue of which it is highly relevant and topical because the non-supply of electricity to industrial and domestic consumers generates national crises and societal imbalances with extreme effects on national security, the vulnerability of the final consumer and the safety of the citizen. In this context, the National Power Grid becomes a strategic objective of national and European importance, by being a generator of critical infrastructure and ensuring the health and safety at work for power substations staff 
(operation, maintenance or dispatching personnel), it is becoming an objective to ensure continuity of electricity processes and energy security. Each power substation listed as a national or European critical infrastructure (cross-border power substation) can generate risks which can jeopardize the safety of the workers through accidents or occupational diseases, therefore, the assessment of occupational health and safety risks has to become a major objective of every power critical infrastructure and must be carried out by highly skilled energy process specialists and specialists or experts in assessing occupational health and safety risks, in the context of securing the workplace and personnel $[4,13,18]$.

\section{The novelty of the study}

OHS Management in terms of very high voltage installations $(400 \mathrm{kV})$ for every power substation listed as critical infrastructure, is a very large area of inter-disciplinarity and multidisciplinarity in the fields of electrical, medical, intelligence and safety, due to the multitude of sources of risks and threats to personnel, with the purpose of finding the most appropriate methods and means of preventing and protecting and ensuring the functionality of workplaces in complete safety, without disrupting the good functioning of national industry and economy.

The most effective way of protecting OHS for personnel from power substation is to eliminate electrical sources of danger, which is an action whose effects are maximum if it is carried out during the design and construction phase of work systems, but which is also beneficial thereafter, provided that a methodology is in place to analyze, identify and determine how to deal with these sources of danger and risk-related personnel.

Since OHS is a major problem for society with regard to national security and the wellbeing of the population, the authors come up with a proposal (novelty): every power substation listed as national or European critical infrastructure, built as a new objective, new or non-refurbished, must be assessed in terms of OHS at least twice a year or whenever the situation requires it (changes in operating systems and schemes or working conditions), with the active and pragmatic involvement of the Romanian state, in order to avoid, prevent and combat possible risks and threats to personnel and work places.

Finally, the role of OHS is to ensure that national industry is in a good working condition, an ergonomic, optimal and healthy working environment, secure personnel and work places, the safety and security of industrial processes, for the purpose of a smooth functioning of the national economy $[5,11,17]$.

\section{Risks assessment in terms of OHS at a cross-border $400 / 220 \mathrm{kV}$ power substation within National Power Sector - European critical infrastructure}

\subsection{Program for assessing conformity with legal and other provisions in force}

Within the $400 / 220 \mathrm{kV}$ power substation exist the followings workplaces $[6,7,12,14]$ :

1) $400 \mathrm{kV}$ and $220 \mathrm{kV}$ Operational Service;

2) $20 \mathrm{kV}$ Operational Service;

3) $400 \mathrm{kV}$ and $220 \mathrm{kV}$ Primary Circuit Maintenance;

4) 20 kV Primary Circuit Maintenance;

5) 20 kV Secondary Circuit Maintenance. 


\subsubsection{Risk level assessment for the activity: $400 \mathrm{kV}$ and $220 \mathrm{kV}$ Operational Service}

The object of the activity is the operational service of the power installations:

- supervision;

- control;

- maneuver.

\section{Means of production:}

$400 \mathrm{kV}$ Power Substation:

- busbars;

- OHL switchgears;

- 400/220 kV AT switchgears;

- coupling switchgears (transversal / longitudinal / longotransversal);

- compensating coil switchgears;

- busbar measuring switchgears; discharge switchgears, etc.

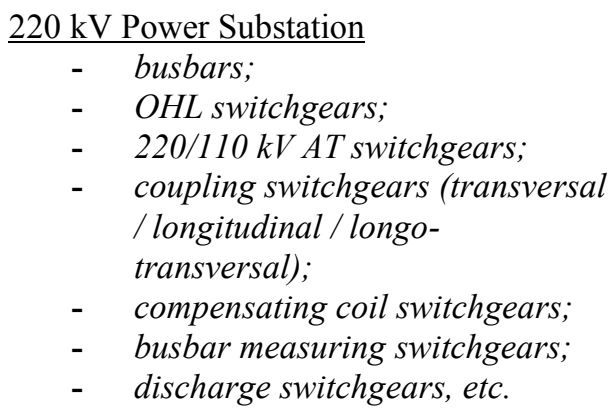

Risk factors specific to the means of production:

- mechanical risk (falling from the same level, slipping or tripping, explosions of equipment with a lifetime exceeded, falling from a height);

- electrical risk (direct contact with electrical installations);

- thermal risk (burns due to electric arc).

2. Work load:

According to the operating regulations, the duties of the operational staff are as follows:

- performing the handover-receiving operations of the work team;

- supervision activity;

- control activity;

- the activity of executing the electric maneuvers.

Risk factors specific to the work load:

- psychic stress in the $400 \mathrm{kV}$ and $220 \mathrm{kV}$ power substations, when installing short circuits by hand.

\section{Performer:}

The following staff works in the power substation:

- manager (s) of the power substations (electrical engineer);

- shift leaders;

- shift leaders aides.

\section{Risk factors specific to the performer:}

- wrong action:

- incorrect identification of the installation and non-verification of the lack of voltage, when mounting the short circuits;

- failure to respect the neighbouring distances with risk of electric shock by direct contact;

- omissions:

- not checking the lack of voltage before mounting the mobile short circuits.

- omissions of operations during manoeuvres, with risk of burns caused by electric arc, when closing grounding knives or mounting the mobile short circuits without checking the lack of voltage; 
- non-use and/or non-verification of the personal protective equipment provided and/or of the electrical insulating means and devices.

\section{Work environment:}

The operating staff carries out the activity in the control room at the external power substations of $400 \mathrm{kV}$ and $220 \mathrm{kV}$, where the specific nature of the work assignment requires operation and control activities regardless of climatic conditions and as a result the main risk factor specific to the working environment is the air temperature by exposure to high or low temperatures during the performances of the work assignment [15].

\section{Risk factors specific to the work environment:}

- physical risk factors:

- exposure to adverse weather conditions (low/high temperatures, rain, snow, air currents) during installations' control.

Table 1. Workplace assessment sheet $400 \mathrm{kV}$ and $220 \mathrm{kV}$ Operational Service

\begin{tabular}{|c|c|c|c|c|c|c|}
\hline \multirow{3}{*}{\multicolumn{2}{|c|}{$\begin{array}{c}\text { NATIONAL POWER } \\
\text { SECTOR } \\
\text { RESPONSIBLE NATIONAL } \\
\text { COMPANY } \\
400 \mathrm{kV} \text { and } 220 \mathrm{kV} \\
\text { OPERATIONAL SERVICE }\end{array}$}} & \multirow{4}{*}{$\begin{array}{c}\text { ASSESSMENT } \\
\text { SHEET } \\
\text { OF WORKPLACE } \\
\text { CONCRETE } \\
\text { FORM OF } \\
\text { MANIFESTATION } \\
\text { OF RISK } \\
\text { FACTORS } \\
\end{array}$} & \multirow{2}{*}{\multicolumn{4}{|c|}{ 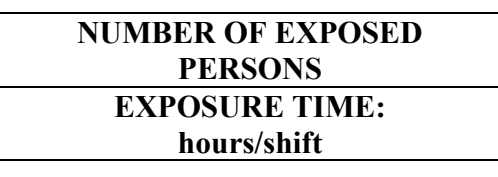 }} \\
\hline & & & & & & \\
\hline & & & \multicolumn{4}{|c|}{ ASSESSMENT TEAM: } \\
\hline $\begin{array}{l}\text { The composition } \\
\text { of the work } \\
\text { system }\end{array}$ & $\begin{array}{l}\text { Identified } \\
\text { risk factors }\end{array}$ & & $\begin{array}{l}\text { Maximum } \\
\text { foreseeable } \\
\text { consequence }\end{array}$ & $\begin{array}{l}\text { Class of } \\
\text { severity }\end{array}$ & $\begin{array}{c}\text { Class of } \\
\text { probability }\end{array}$ & $\begin{array}{l}\text { Risk } \\
\text { level }\end{array}$ \\
\hline \multirow{4}{*}{$\begin{array}{l}\text { MEANS OF } \\
\text { PRODUCTION }\end{array}$} & $\begin{array}{l}\text { Mechanical } \\
\text { risk } \\
\text { factors: } \\
\text { - falling } \\
\text { from the } \\
\text { same level }\end{array}$ & $\begin{array}{lr}\text { 1. Falling } & \text { due to } \\
\text { distraction } & \text { when } \\
\text { moving } & \text { through } \\
\text { outside } & \text { power } \\
\text { substations } & \end{array}$ & $\begin{array}{l}\text { Temporary } \\
\text { Work } \\
\text { Incapacity } \\
3-45 \text { days }\end{array}$ & 2 & 1 & 1 \\
\hline & \multirow{2}{*}{$\begin{array}{l}\text { Electrical } \\
\text { risk } \\
\text { factors: } \\
\text { - electrical } \\
\text { shock } \\
\text { hazard }\end{array}$} & $\begin{array}{l}\text { 2. Not using two } \\
\text { mobile short circuits } \\
\text { in the working area }\end{array}$ & DEATH & 7 & 2 & 4 \\
\hline & & $\begin{array}{l}\text { 3. Not using in } \\
\text { working area of } \\
\text { capacitive load } \\
\text { damper (in case of } \\
\text { capacitive currents) }\end{array}$ & DEATH & 7 & 2 & 4 \\
\hline & $\begin{array}{l}\text { Thermal } \\
\text { risk } \\
\text { factors: } \\
\text { - explosion } \\
\text { hazard } \\
\end{array}$ & $\begin{array}{l}\text { 4. Explosion of } \\
\text { power, voltage, and } \\
\text { current transformers, } \\
\text { discharge }\end{array}$ & DEATH & 7 & 1 & 3 \\
\hline \multirow[b]{2}{*}{ PERFORMER } & \multirow{2}{*}{$\begin{array}{l}\text { Wrong } \\
\text { actions: } \\
\text { - omission } \\
\text { of present } \\
\text { operations; } \\
\text { - not using } \\
\text { of means of } \\
\text { protections }\end{array}$} & $\begin{array}{l}\text { 5. Not checking the } \\
\text { lack of voltage before } \\
\text { mounting the mobile } \\
\text { short circuits }\end{array}$ & DEATH & 7 & 2 & 4 \\
\hline & & $\begin{array}{l}\text { 6. Failure to use or } \\
\text { verify personal } \\
\text { protective } \\
\text { equipment, tools and } \\
\text { electro-insulating } \\
\text { devices provided }\end{array}$ & DEATH & 7 & 1 & 3 \\
\hline
\end{tabular}




\begin{tabular}{|c|l|l|l|l|l|l|}
\hline WORK & $\begin{array}{l}\text { Risk } \\
\text { factors: } \\
\text { ENVIRONMENT }\end{array}$ & $\begin{array}{l}7 . \text { Exposure to } \\
\text { adverse weather } \\
\text { conditions (high, low } \\
\text { temperatures), when } \\
\text { temperature } \\
\text { operating in outdoor } \\
\text { power substations }\end{array}$ & $\begin{array}{c}\text { Temporary } \\
\text { Incapacity }\end{array}$ & 2 & 1 & 1 \\
\hline
\end{tabular}

The global risk level at workplace: $400 \mathrm{kV}$ and $220 \mathrm{kV}$ Operational Service

$$
N_{400 \mathrm{kV}-220 \mathrm{kV}}=\frac{\sum_{i=1}^{7} R_{i} \cdot r_{i}}{\sum_{i=1}^{7} r_{i}}=\frac{2 \cdot(1 \cdot 1)+2 \cdot(3 \cdot 3)+3 \cdot(4 \cdot 4)}{2 \cdot 1+2 \cdot 3+3 \cdot 4}=\frac{68}{20}=3,4
$$

Table 2. Proposed measures sheet $-400 \mathrm{kV}$ and $220 \mathrm{kV}$ Operational Service

\begin{tabular}{|c|c|c|c|}
\hline No. & RISK FACTOR & $\begin{array}{c}\text { RISK } \\
\text { LEVEL }\end{array}$ & $\begin{array}{l}\text { PROPOSED PREVENTION } \\
\text { MEASURES }\end{array}$ \\
\hline 1. & $\begin{array}{l}\text { Not using two mobile short circuits in } \\
\text { the working area }\end{array}$ & 4 & \multirow{3}{*}{$\begin{array}{l}\text { Training and unannounced and } \\
\text { regular control by the management }\end{array}$} \\
\hline 2. & $\begin{array}{l}\text { Not using in working area of } \\
\text { capacitive load damper (in case of } \\
\text { capacitive currents) }\end{array}$ & 4 & \\
\hline 3. & $\begin{array}{l}\text { Not checking the lack of voltage } \\
\text { before mounting the mobile short } \\
\text { circuits }\end{array}$ & 4 & \\
\hline
\end{tabular}

\subsubsection{Risk level assessment for activity: 20 kV Operational Service}

The object of the activity is the operational service of the power installations:

- supervision;

- control;

- maneuver.

1. Means of production:

$20 \mathrm{kV}$ Power Substation:

- busbars;

- OHL switchgears;

- 110/20 kV AT switchgears;

- coupling switchgears (transversal / longitudinal / longo-transversal);

- compensating coil switchgears;

- busbar measuring switchgears;

- discharge switchgears, etc.

Risk factors specific to the means of production:

- mechanical risk (falling from the same level, slipping or tripping, explosions of equipment with exceeded lifetime, falling from a height);

- electrical risk (direct contact with electrical installations);

- thermal risk (burns due to electric arc).

\section{Work load:}

According to the operating regulations, the duties of the operational staff are as follows:

- performing the handover-receiving operations of the work team;

- supervision activity;

- control activity;

- the activity of executing the electric maneuvers. 


\section{Risk factors specific to the work load:}

- psychic stress in the $20 \mathrm{kV}$ power substations, when installing short circuits by hand.

3. Performer:

The following staff works in the power substation:

- manager (s) power substations (electrical engineer)

- shift leaders;

- shift leaders aides.

Risk factors specific to the performer:

- wrong action:

- incorrect identification of the installation and non-verification of the lack of voltage, when mounting the short circuits; contact;

- failure to respect the neighbouring distances with risk of electric shock by direct

- not checking the lack of voltage before mounting the mobile short circuits.

- omissions:

- omissions of operations during maneuvers, with risk of burns caused by electric arc, when closing grounding knives or mounting the mobile short circuits without checking the lack of voltage;

- non-use and/or non-verification of the personal protective equipment provided and/or of the electrical insulating means and devices.

\section{Work environment:}

The operating staff carries out the activity in the control room at the external power substations of $20 \mathrm{kV}$, where the specific nature of the work assignment requires operation and control activities regardless of climatic conditions and as a result the main risk factor specific to the working environment is the air temperature by exposure to high or low temperatures during the performances of the work assignment [16].

\section{Risk factors specific to the work environment:}

- physical risk factors:

- exposure to adverse weather conditions (low/high temperatures, rain, snow, air currents) during installations' control.

Table 3. Workplace assessment sheet $20 \mathrm{kV}$ Operational Service

\begin{tabular}{|c|c|c|c|c|c|c|}
\hline \multirow{3}{*}{\multicolumn{2}{|c|}{$\begin{array}{c}\text { NATIONAL POWER } \\
\text { SECTOR } \\
\text { RESPONSIBLE NATIONAL } \\
\text { COMPANY } \\
20 \mathrm{kV} \text { OPERATIONAL } \\
\text { SERVICE }\end{array}$}} & \multirow{4}{*}{$\begin{array}{c}\text { ASSESSMENT } \\
\text { SHEET } \\
\text { OF WORKPLACE } \\
\text { CONCRETE } \\
\text { FORM OF } \\
\text { MANIFESTATIO } \\
\text { N OF RISK } \\
\text { FACTORS } \\
\end{array}$} & \multirow{2}{*}{\multicolumn{4}{|c|}{$\begin{array}{c}\text { NUMBER OF EXPOSED } \\
\text { PERSONS } \\
\begin{array}{c}\text { EXPOSURE TIME: } \\
\text { hours/shift }\end{array} \\
\end{array}$}} \\
\hline & & & & & & \\
\hline & & & & & & \\
\hline \multirow[t]{2}{*}{$\begin{array}{c}\text { The composition } \\
\text { of the work } \\
\text { system }\end{array}$} & $\begin{array}{l}\text { Identified } \\
\text { risk factors }\end{array}$ & & $\begin{array}{l}\text { Maximum } \\
\text { foreseeable } \\
\text { consequence }\end{array}$ & $\begin{array}{l}\text { Class of } \\
\text { severity }\end{array}$ & $\begin{array}{c}\text { Class of } \\
\text { probability }\end{array}$ & $\begin{array}{l}\text { Risk } \\
\text { level }\end{array}$ \\
\hline & $\begin{array}{l}\text { Mechanical } \\
\text { risk factors: }\end{array}$ & $\begin{array}{l}\text { 1. Short circuit } \\
\text { breaker explosions }\end{array}$ & DEATH & 7 & 1 & 3 \\
\hline
\end{tabular}




\begin{tabular}{|c|c|c|c|c|c|c|}
\hline \multirow[t]{5}{*}{$\begin{array}{c}\text { MEANS OF } \\
\text { PRODUCTIO } \\
\mathbf{N}\end{array}$} & $\begin{array}{l}\text { Hazard } \\
\text { movements: } \\
-\quad \text { movement } \\
\text { under } \\
\text { propulsion } \\
\end{array}$ & $\begin{array}{l}2 . \quad \text { Discharging } \\
\text { explosions during } \\
\text { operation }\end{array}$ & DEATH & 7 & 1 & 3 \\
\hline & \multirow{3}{*}{$\begin{array}{l}\text { Electrical } \\
\text { risk } \\
\text { factors: } \\
\text { - electric } \\
\text { current }\end{array}$} & $\begin{array}{l}\text { 3. Touching of } \\
\text { unmarked terminals } \\
\text { and installations }\end{array}$ & DEATH & 7 & 1 & 3 \\
\hline & & $\begin{array}{lr}\begin{array}{l}\text { 4. Touching } \\
\text { installations }\end{array} \\
\begin{array}{l}\text { connecting } \\
\text { circuits }\end{array} & \text { short } \\
& \\
\end{array}$ & DEATH & 7 & 1 & 3 \\
\hline & & $\begin{array}{l}\text { 5. Touching the } 20 \\
\mathrm{kV} \text { busbars during } \\
\text { maneuvers }\end{array}$ & DEATH & 7 & 1 & 3 \\
\hline & $\begin{array}{l}\text { Thermal } \\
\text { risk factors: } \\
-\quad \text { flames, } \\
\text { flame } \\
\end{array}$ & $\begin{array}{l}\text { 6. Burns due to short } \\
\text { circuits caused by } \\
\text { insulation breaks and } \\
\text { explosions }\end{array}$ & DEATH & 7 & 1 & 3 \\
\hline WORK LOAD & \begin{tabular}{|l} 
Inadequate \\
work load \\
content \\
relative to \\
requirement \\
s security \\
\end{tabular} & $\begin{array}{l}\text { 7. Mounting short } \\
\text { circuits by hand }\end{array}$ & DEATH & 7 & 1 & 3 \\
\hline \multirow{4}{*}{ PERFORMER } & \multirow[b]{2}{*}{$\begin{array}{l}\text { Wrong } \\
\text { actions }\end{array}$} & $\begin{array}{l}\text { 8. Failure to respect } \\
\text { the neighbouring } \\
\text { distances with risk of } \\
\text { electric shock by } \\
\text { direct contact. }\end{array}$ & DEATH & 7 & 1 & 3 \\
\hline & & $\begin{array}{l}\text { 9. Failure to verify } \\
\text { the position and/or } \\
\text { condition of the } \\
\text { components to be } \\
\text { operated when } \\
\text { maneuvering }\end{array}$ & DEATH & 7 & 1 & 3 \\
\hline & \begin{tabular}{|l} 
Omissions: \\
- omission of \\
operations \\
present in \\
the \\
Maneuver \\
Sheet \\
\end{tabular} & $\begin{array}{l}\text { 10. Not checking the } \\
\text { lack of voltage } \\
\text { before installing } \\
\text { mobile short } \\
\text { circuiting or closing } \\
\text { the grounding knives }\end{array}$ & DEATH & 7 & 1 & 3 \\
\hline & $\begin{array}{l}\text { - not using of } \\
\text { means of } \\
\text { protection }\end{array}$ & $\begin{array}{l}\text { 11. Failure to use or } \\
\text { check personal } \\
\text { protective } \\
\text { equipment, tools and } \\
\text { electro-insulating } \\
\text { devices }\end{array}$ & DEATH & 7 & 1 & 3 \\
\hline
\end{tabular}

The global risk level at workplace: $20 \mathrm{kV}$ Operational Service

$$
N_{20 \mathrm{kV}}=\frac{\sum_{i=1}^{11} R_{i} \cdot r_{i}}{\sum_{i=1}^{11} r_{i}}=\frac{11 \cdot(3 \cdot 3)}{11 \cdot 3}=\frac{99}{33}=3,00
$$


Table 4. Proposed measures sheet $-20 \mathrm{kV}$ Operational Service

\begin{tabular}{|c|c|c|c|}
\hline No. & RISK FACTOR & RISK & PROPOSED PREVENTION \\
LEVEL & MEASURES \\
\hline- & - & - & - \\
\hline
\end{tabular}

\subsubsection{Risk level assessment for activity: $400 \mathrm{kV}$ and $220 \mathrm{kV}$ Primary Circuit} Maintenance

The purpose of maintenance and repair of primary equipment is the following types of work:

- servicing primary equipment;

- mechanical activities;

- welding and painting activity;

- masonry repair;

- dismantling of appliances.

1. Means of production:

$400 \mathrm{kV}$ Power Substation:

- busbars;

- OHL switchgears;

- 400/220 kV AT switchgears;

- coupling switchgears (transversal

$220 \mathrm{kV}$ Power Substation

- busbars;

- OHL switchgears;

- 220/110 kV AT switchgears;

/ longitudinal / longotransversal);

- compensating coil switchgears;

- busbar measuring switchgears;

- discharge switchgears, etc.

- coupling switchgears (transversal / longitudinal / longotransversal);

- compensating coil switchgears;

- busbar measuring switchgears;

- discharge switchgears, etc.

Risk factors specific to the means of production:

- mechanical risk factors:

- hazardous movements;

- cutting edges and sharp corners when replacing broken insulators;

- explosion of molten metal particles or electric shock to electric welding;

- explosions at transformers.

\section{Work load:}

Work load of the service and repair team is to:

- technical revisions (TR) - annually on all equipment in the power substations;

- current revisions (RC) - changes in sub-assemblies, replacement of power substation components;

- accidental interventions - in the event of faults or failures in primary equipment;

- maintenance of auxiliary installations;

- maintenance work on the power substation;

- changes of lighting fittings.

\section{Risk factors specific to the work load:}

- failure to properly prepare and/or failure to comply with the required steps in the performance of maintenance activities;

- failure to comply with measures to ensure the working area;

- oversized physical effort when removing the cutting-off switches from the switchgears.

\section{Performer:}

The service-repair team the primary equipment is composed of electricians who are led by a master. 
Risk factors specific to the performer:

- wrong action:

- misidentification of the installations in which work is being carried out;

- wrong maneuvers when performing operational tests;

- exceeding proximity distances when transporting materials to the work area and during work;

- displacement, stationing in hazardous areas outside the working area;

- falling from the same level by unbalancing, during the transport of materials within the area of the power substation,

- omissions:

- non-use of personal protective equipment as provided or use of non-certified personal protective equipment.

\section{Work environment:}

Service activity - primary equipment repair is carried out in the external power substation and very rarely in the mechanical room.

Risk factors specific to the work environment:

- physical risk factors:

- inhalation of noxious in paint work;

- bad weather conditions (high/low temperature, wind).

Table 5. Workplace assessment sheet $400 \mathrm{kV}$ and $220 \mathrm{kV}$ Primary Circuit Maintenance

\begin{tabular}{|c|c|c|c|c|c|c|}
\hline \multicolumn{2}{|c|}{ NATIONAL POWER SECTOR } & \multirow{3}{*}{$\begin{array}{l}\text { ASSESSMENT } \\
\text { SHEET } \\
\text { OF } \\
\text { WORKPLACE }\end{array}$} & \multicolumn{4}{|c|}{$\begin{array}{l}\text { NUMBER OF EXPOSED } \\
\text { PERSONS }\end{array}$} \\
\hline \multicolumn{2}{|c|}{$\begin{array}{l}\text { RESPONSIBLE NATIONAL } \\
\text { COMPANY }\end{array}$} & & \multicolumn{4}{|c|}{$\begin{array}{c}\text { EXPOSURE TIME: } \\
\text { hours/shift }\end{array}$} \\
\hline $\begin{array}{r}400 \text { and } 220 \mathrm{k} \\
\text { CIRCUIT MA }\end{array}$ & $\begin{array}{l}\text { PRIMARY } \\
\text { NTENANCE }\end{array}$ & & \multicolumn{4}{|c|}{ ASSESSMENT TEAM: } \\
\hline $\begin{array}{l}\text { The composition } \\
\text { of the work } \\
\text { system }\end{array}$ & $\begin{array}{l}\text { Identified risk } \\
\text { factors }\end{array}$ & $\begin{array}{c}\text { CONCRETE } \\
\text { FORM } \\
\text { MANIFESTATI } \\
\text { ON OF RISK } \\
\text { FACTORS } \\
\end{array}$ & $\begin{array}{c}\text { Maximum } \\
\text { foreseeable } \\
\text { consequence }\end{array}$ & $\begin{array}{l}\text { Class of } \\
\text { severity }\end{array}$ & $\begin{array}{c}\text { Class of } \\
\text { probability }\end{array}$ & $\begin{array}{l}\text { Risk } \\
\text { level }\end{array}$ \\
\hline \multirow[b]{3}{*}{$\begin{array}{l}\text { MEANS OF } \\
\text { PRODUCTION }\end{array}$} & \multirow{2}{*}{$\begin{array}{l}\text { Mechanical } \\
\text { risk factors: } \\
\text { - functional } \\
\text { movements of } \\
\text { technical } \\
\text { machinery }\end{array}$} & $\begin{array}{l}\text { 1. Displacement by } \\
\text { means of transport } \\
\text { to the workplace - } \\
\text { road accident; }\end{array}$ & DEATH & 7 & 1 & 3 \\
\hline & & $\begin{array}{l}\text { 2. Hazardous } \\
\text { surfaces }\end{array}$ & $\begin{array}{l}\text { Temporary } \\
\text { Work } \\
\text { Incapacity }\end{array}$ & 2 & 2 & 2 \\
\hline & $\begin{array}{l}\text { Thermal risk } \\
\text { factors }\end{array}$ & $\begin{array}{l}\text { 3. Injury by the } \\
\text { thermal effect of } \\
\text { the electric arc for } \\
\text { service and repair } \\
\text { personnel when } \\
\text { traveling on the } \\
\text { area of power } \\
\text { substations for } \\
\text { fulfilling the work } \\
\text { load }\end{array}$ & $\begin{array}{l}\text { 1st degree } \\
\text { Disability }\end{array}$ & 6 & 1 & 3 \\
\hline
\end{tabular}




\begin{tabular}{|c|c|c|c|c|c|c|}
\hline & $\begin{array}{l}\text { Electrical } \\
\text { risk factors } \\
\text { - indirect } \\
\text { touch }\end{array}$ & $\begin{array}{l}\text { 4. Touching of } \\
\text { metal parts } \\
\text { accidentally under } \\
\text { voltage, in } \\
\text { conditions of: } \\
\text { - damage to } \\
\text { insulation from the } \\
\text { metal housing; } \\
\text { - failure of the } \\
\text { protective } \\
\text { connection }\end{array}$ & DEATH & 7 & 2 & 4 \\
\hline & $\begin{array}{l}\text { Improper } \\
\text { content in } \\
\text { relation to } \\
\text { security } \\
\text { requirements }\end{array}$ & $\begin{array}{l}5 . \quad \text { Improper } \\
\text { preparation and/or } \\
\text { non-compliance } \\
\text { with mandatory } \\
\text { steps and measures } \\
\text { to secure the work } \\
\text { area }\end{array}$ & DEATH & 7 & 1 & 3 \\
\hline WORK LOAD & $\begin{array}{l}\text { Under/oversiz } \\
\text { ed workload in } \\
\text { relation to the } \\
\text { capacity of the } \\
\text { performer }\end{array}$ & $\begin{array}{l}\text { 6. Dynamic, static } \\
\text { effort, forced } \\
\text { working positions } \\
\text { at ground and } \\
\text { height when } \\
\text { handling and } \\
\text { replacing } \\
\text { subassemblies and } \\
\text { components of } \\
\text { primary } \\
\text { equipment, } \\
\text { insulators } \\
\text { replacement }\end{array}$ & $\begin{array}{l}\text { Temporary } \\
\text { Work } \\
\text { Incapacity } \\
45-180 \\
\text { days }\end{array}$ & 3 & 2 & 2 \\
\hline $\begin{array}{c}\text { WORK } \\
\text { ENVIRONME } \\
\text { NT }\end{array}$ & $\begin{array}{l}\text { Physical risk } \\
\text { factors }\end{array}$ & $\begin{array}{l}\text { 7. Inhalation of } \\
\text { toxic dust and } \\
\text { gases in the while } \\
\text { performing } \\
\text { painting operations }\end{array}$ & $\begin{array}{l}\text { Temporar } \\
\text { y Work } \\
\text { Incapacity } \\
45-180 \\
\text { days } \\
\end{array}$ & 3 & 2 & 2 \\
\hline \multirow{4}{*}{ PERFORMER } & \multirow{4}{*}{ Wrong actions } & $\begin{array}{l}8 . \\
\text { identification of the } \\
\text { installations in } \\
\text { which they work, } \\
\text { wrong maneuvers } \\
\text { when performing } \\
\text { functional tests }\end{array}$ & DEATH & 7 & 1 & 3 \\
\hline & & $\begin{array}{l}9 . \quad \text { Entering the } \\
\text { work area } \\
\text { unprepared in } \\
\text { terms of work } \\
\text { safety }\end{array}$ & DEATH & 7 & 1 & 3 \\
\hline & & $\begin{array}{l}10 . \quad \text { Incomplete } \\
\text { work permit } \\
\text { without specifying } \\
\text { all working area } \\
\text { insurance } \\
\text { conditions }\end{array}$ & DEATH & 7 & 2 & 4 \\
\hline & & $\begin{array}{l}\text { 11. Exceeding } \\
\text { neighbouring } \\
\text { distances }\end{array}$ & DEATH & 7 & 1 & 3 \\
\hline
\end{tabular}




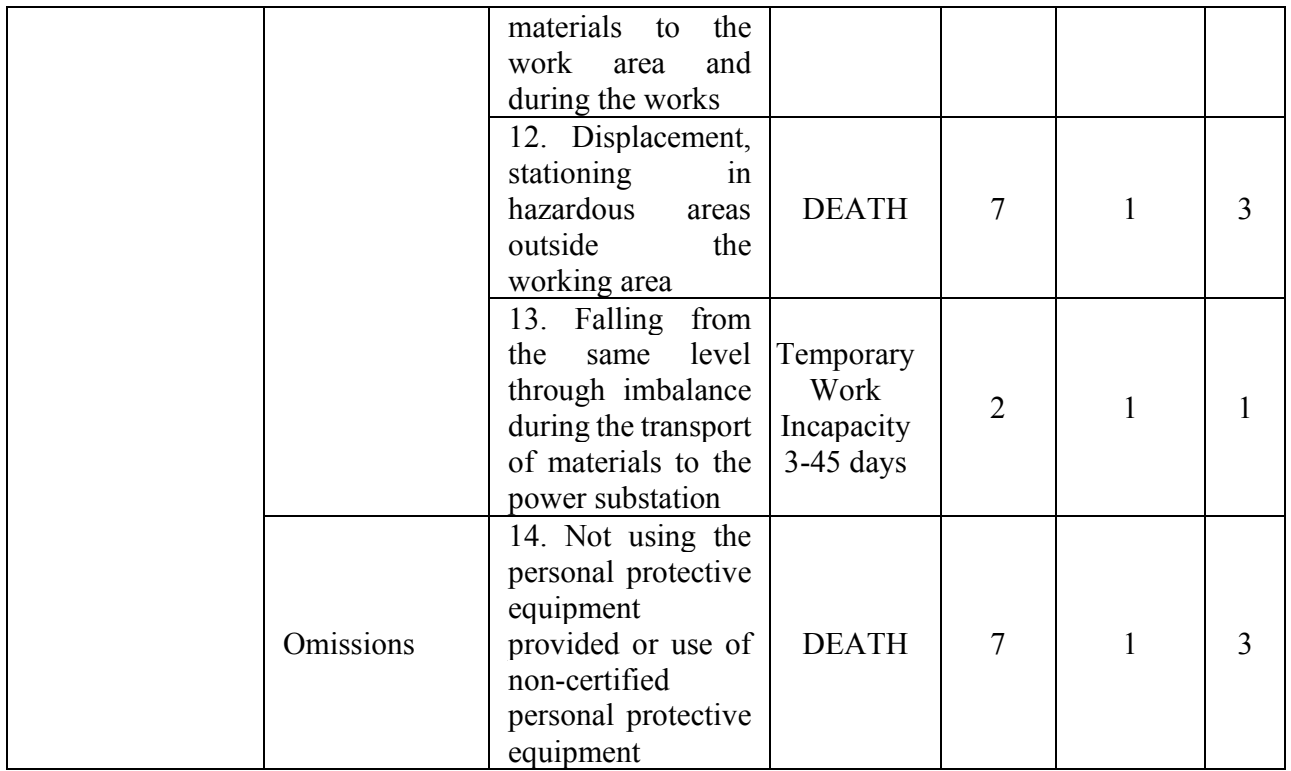

The global risk level at workplace: $400 \mathrm{kV}$ and $220 \mathrm{kV}$ Primary Circuit Maintenance

$$
\begin{gathered}
N_{\text {MENT.EP400/220kV }}=\frac{\sum_{i=1}^{14} R_{I} \cdot r_{i}}{\sum_{i=1}^{14} r_{i}}= \\
=\frac{1 \cdot(1 \cdot 1)+3 \cdot(2 \cdot 2)+8 \cdot(3 \cdot 3)+2 \cdot(4 \cdot 4)}{1 \cdot 1+3 \cdot 2+8 \cdot 3+2 \cdot 4}=\frac{101}{39}=2,58
\end{gathered}
$$

Table 6. Proposed measures sheet $-400 \mathrm{kV}$ and $220 \mathrm{kV}$ Primary Circuit Maintenance

\begin{tabular}{|c|l|c|l|}
\hline No. & \multicolumn{1}{|c|}{ RISK FACTOR } & \multicolumn{1}{|c|}{$\begin{array}{c}\text { RISK } \\
\text { LEVEL }\end{array}$} & \multicolumn{1}{c|}{$\begin{array}{c}\text { PROPOSED PREVENTIVE } \\
\text { MEASURES }\end{array}$} \\
\hline 1 & $\begin{array}{l}\text { Touching of accidentally live metal } \\
\text { parts under the conditions ok: } \\
\text { - damage to the insulation from the } \\
\text { metal housing; } \\
\text {-failure of the protective connection }\end{array}$ & 4 & $\begin{array}{l}\text { Making connections to the earthing } \\
\text { of all technical equipment. } \\
\text { Measurements of touch voltages. } \\
\text { Compliance with the deadlines for } \\
\text { technical revisions. }\end{array}$ \\
\hline 2 & $\begin{array}{l}\text { Incomplete work permit without } \\
\text { specifying all working area insurance } \\
\text { conditions }\end{array}$ & 4 & $\begin{array}{l}\text { Starting of work only on the gasis of } \\
\text { a work permit specifying all the } \\
\text { conditions for securing the work } \\
\text { area }\end{array}$ \\
\hline
\end{tabular}

\subsubsection{Risk level assessment for activity: 20 kV Primary Circuit Maintenance}

The purpose of maintenance and repair of primary equipment is the following types of work:

- servicing primary equipment;

- mechanical activities;

- welding and painting activity;

- masonry repair;

- dismantling of appliances. 
1. Means of production:

$20 \mathrm{kV}$ Power Substation:

- busbars;

- OHL switchgears;

- 110/20 kV AT switchgears;

- coupling switchgears (transversal / longitudinal / longo-transversal);

- compensating coil switchgears;

- busbar measuring switchgears;

- discharge switchgears, etc.

Risk factors specific to the means of production:

- mechanical risk factors:

- hazardous movements;

- cutting edges and sharp corners when replacing broken insulators;

- explosion of molten metal particles or electric shock to electric welding;

- explosions at transformers.

When assessing the severity and probability of manifestation of these risk factors, the age of $20 \mathrm{kV}$ power substations is also taken into account, an age that amplifies the accidental potential of electrical equipment.

\section{Work load:}

Work load of the service and repair team is to:

- technical revisions (TR) - annually on all equipment in the power substations;

- current revisions $(R C)$ - changes in sub-assemblies, replacement of power substation components;

- accidental interventions - in the event of faults or failures in primary equipment;

- maintenance of auxiliary installations;

- maintenance work on the power substation;

- changes of lighting fittings.

Risk factors specific to the work load:

- failure to properly prepare and/or fail to comply with the required steps in the performance of maintenance activities;

- failure to comply with measures to ensure the working area;

- oversized physical effort when removing the cutting-off switches from the switchgears.

\section{Performer:}

The primary service-repair team for equipment is composed of electricians who are led by a master.

\section{Risk factors specific to the performer:}

- wrong action:

- misidentification of the installations in which work is being carried out;

- wrong maneuvers when performing operational tests;

- exceeding proximity distances when transporting materials towards the work area and during work;

- displacements, stationing in hazardous areas outside the working area;

- falling from the same level by unbalancing, during the transport of materials within the area of the power substation.

- omissions:

- non-use of personal protective equipment as provided or use of non-certified personal protective equipment. 


\section{Work environment:}

Service activity - primary equipment repair is carried out in the external power substation and very rarely in the mechanical room.

Risk factors specific to the work environment:

- physical risk factors:

- inhalation of noxious during in paint work;

- bad weather conditions (high/low temperature, wind).

Table 7. Workplace assessment sheet $20 \mathrm{kV}$ Primary Circuit Maintenance

\begin{tabular}{|c|c|c|c|c|c|c|}
\hline \multicolumn{2}{|c|}{ NATIONAL POWER SECTOR } & \multirow{3}{*}{$\begin{array}{l}\text { ASSESSMENT } \\
\text { SHEET } \\
\text { OF } \\
\text { WORKPLACE }\end{array}$} & \multicolumn{4}{|c|}{$\begin{array}{l}\text { NUMBER OF EXPOSED } \\
\text { PERSONS }\end{array}$} \\
\hline \multicolumn{2}{|c|}{$\begin{array}{l}\text { RESPONSIBLE NATIONAL } \\
\text { COMPANY }\end{array}$} & & \multicolumn{4}{|c|}{$\begin{array}{c}\text { EXPOSURE TIME: } \\
\text { hours/shift }\end{array}$} \\
\hline \multicolumn{2}{|c|}{$\begin{array}{c}20 \text { kV PRIMARY CIRCUIT } \\
\text { MAINTENANCE }\end{array}$} & & \multicolumn{4}{|c|}{ ASSESSMENT TEAM: } \\
\hline $\begin{array}{l}\text { The composition } \\
\text { of the work } \\
\text { system }\end{array}$ & $\begin{array}{l}\text { Identified risk } \\
\text { factors }\end{array}$ & $\begin{array}{c}\text { CONCRETE } \\
\text { FORM } \\
\text { MANIFESTATI } \\
\text { ON OF RISK } \\
\text { FACTORS } \\
\end{array}$ & $\begin{array}{l}\text { Maximum } \\
\text { foreseeable } \\
\text { consequence }\end{array}$ & $\begin{array}{l}\text { Class of } \\
\text { severity }\end{array}$ & $\begin{array}{c}\text { Class of } \\
\text { probability }\end{array}$ & $\begin{array}{l}\text { Risk } \\
\text { level }\end{array}$ \\
\hline \multirow{6}{*}{$\begin{array}{l}\text { MEANS OF } \\
\text { PRODUCTION }\end{array}$} & \multirow{4}{*}{$\begin{array}{l}\text { Mechanical } \\
\text { risk factors: } \\
\text { - functional } \\
\text { movements of } \\
\text { technical } \\
\text { machinery } \\
\text { - hazardous } \\
\text { surfaces }\end{array}$} & $\begin{array}{l}\text { 1. Traveling by } \\
\text { means of transport } \\
\text { to the workplace - } \\
\text { road accident }\end{array}$ & DEATH & 7 & 2 & 4 \\
\hline & & $\begin{array}{l}2 . \\
\text { caused by the } \\
\text { tension of the MR } \\
\text { spring during the } \\
\text { adjustment } \\
\text { operation The MRI } \\
\text { actuator of the IO } \\
20 \mathrm{kV} \text { circuit } \\
\text { breaker }\end{array}$ & $\begin{array}{l}\text { 3st degree } \\
\text { Disability }\end{array}$ & 4 & 2 & 3 \\
\hline & & $\begin{array}{l}\text { 3. Cutting edges, } \\
\text { sting when } \\
\text { replacing broken } \\
\text { insulators, TT, TC } \\
\text { and damaged } \\
\text { discharge devices }\end{array}$ & $\begin{array}{l}\text { Temporary } \\
\text { Work } \\
\text { Incapacity } \\
3-45 \text { days }\end{array}$ & 2 & 4 & 2 \\
\hline & & $\begin{array}{l}\text { 4. Hazard of } \\
\text { explosion TIRBO } \\
\text { transformers }\end{array}$ & DEATH & 7 & 2 & 4 \\
\hline & $\begin{array}{l}\text { Thermal risk } \\
\text { factors }\end{array}$ & $\begin{array}{l}\text { 5. Injury by the } \\
\text { thermal effect of } \\
\text { the electric arc of } \\
\text { service and repair } \\
\text { personnel when } \\
\text { traveling on the } \\
\text { territory power } \\
\text { substations of the } \\
\text { work load }\end{array}$ & $\begin{array}{l}\text { 1st degree } \\
\text { Disability }\end{array}$ & 6 & 4 & 6 \\
\hline & $\begin{array}{l}\text { Electrical } \\
\text { risk factors } \\
\text { - indirect } \\
\text { touch } \\
\end{array}$ & $\begin{array}{l}\text { 6. Touching of } \\
\text { accidentally live } \\
\text { metal parts under } \\
\text { the conditions: }\end{array}$ & DEATH & 7 & 4 & 6 \\
\hline
\end{tabular}




\begin{tabular}{|c|c|c|c|c|c|c|}
\hline & & $\begin{array}{l}- \text { damage to } \\
\text { insulation from the } \\
\text { metal housing; } \\
-\quad \text { failure of the } \\
\text { protective } \\
\text { connection }\end{array}$ & & & & \\
\hline \multirow[b]{2}{*}{ WORK LOAD } & $\begin{array}{l}\text { Inadequate } \\
\text { content in } \\
\text { relation to } \\
\text { security } \\
\text { requirements }\end{array}$ & $\begin{array}{l}7 . \quad \text { Adequate } \\
\text { preparation and/or } \\
\text { non-compliance } \\
\text { with mandatory } \\
\text { steps and measures } \\
\text { to secure the work } \\
\text { area }\end{array}$ & DEATH & 7 & 3 & 5 \\
\hline & $\begin{array}{l}\text { Under/oversiz } \\
\text { ed workload in } \\
\text { relation to the } \\
\text { capacity of the } \\
\text { performer }\end{array}$ & $\begin{array}{lr}\text { 8. Dynamic, static } \\
\text { effort, forced } \\
\text { working positions } \\
\text { at ground and } \\
\text { height rhen } \\
\text { handling and } \\
\text { replacing } \\
\text { subassemblies and } \\
\text { components of } \\
\text { primary } \\
\text { equipments, } \\
\text { insulating } \\
\text { replacement }\end{array}$ & $\begin{array}{l}\text { Temporary } \\
\text { Work } \\
\text { Incapacity } \\
\text { 45-180 days }\end{array}$ & 3 & 4 & 3 \\
\hline $\begin{array}{c}\text { WORK } \\
\text { ENVIRONME } \\
\text { NT }\end{array}$ & $\begin{array}{l}\text { Physical risk } \\
\text { factors }\end{array}$ & $\begin{array}{l}\text { 9. Inhalation of } \\
\text { toxic dust and } \\
\text { gases in the } \\
\text { execution of the } \\
\begin{array}{l}\text { operations } \\
\text { painting of }\end{array}\end{array}$ & $\begin{array}{l}\text { Temporary } \\
\text { Work } \\
\text { Incapacity } \\
\text { 45-180 days }\end{array}$ & 3 & 2 & 2 \\
\hline \multirow{5}{*}{ PERFORMER } & \multirow{5}{*}{ Wrong actions } & $\begin{array}{l}10 . \text { Incorrect } \\
\text { identification of the } \\
\text { installations in } \\
\text { which they work, } \\
\text { wrong maneuvers } \\
\text { when performing } \\
\text { functional tests }\end{array}$ & DEATH & 7 & 4 & 6 \\
\hline & & $\begin{array}{lr}11 . \text { Entering } & \text { the } \\
\text { work } & \text { area } \\
\text { unprepared } & \text { for } \\
\text { work safety } & \\
\end{array}$ & DEATH & 7 & 4 & 6 \\
\hline & & $\begin{array}{l}12 . \quad \text { Incomplete } \\
\text { work permit } \\
\text { without specifying } \\
\text { all working area } \\
\text { insurance } \\
\text { conditions }\end{array}$ & DEATH & 7 & 4 & 6 \\
\hline & & $\begin{array}{l}\text { 13. Exceeding the } \\
\text { distances of } \\
\text { materials to the } \\
\text { work area and } \\
\text { during the works }\end{array}$ & DEATH & 7 & 3 & 5 \\
\hline & & $\begin{array}{lr}14 . & \text { Journeys, } \\
\text { stationing in } \\
\text { hazardous }\end{array}$ & DEATH & 7 & 3 & 5 \\
\hline
\end{tabular}




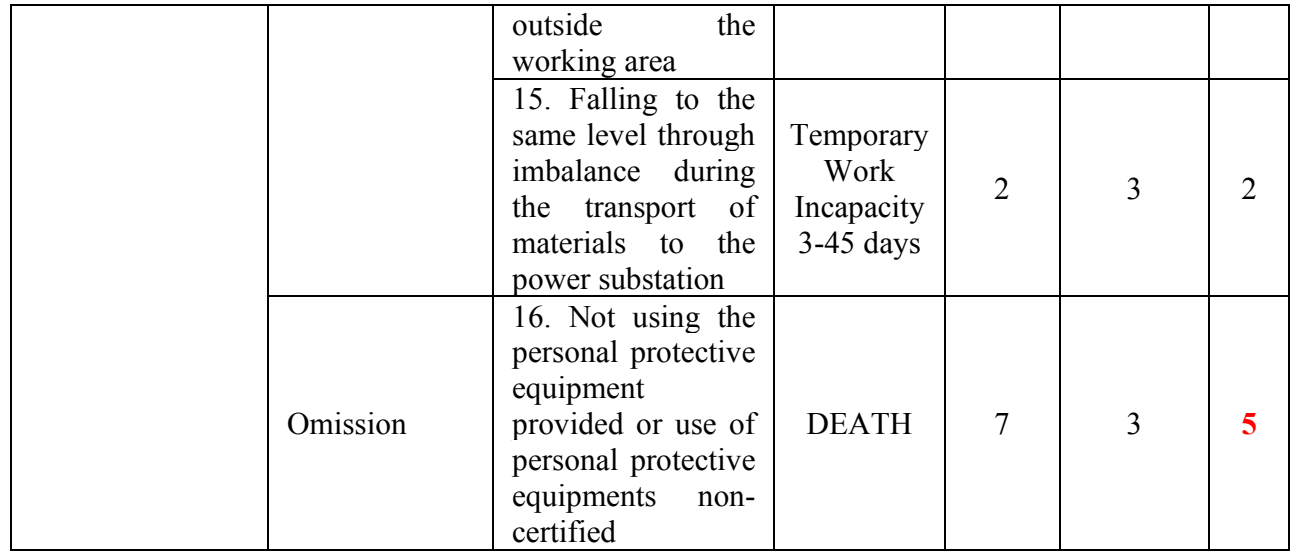

The global risk level at workplace: $20 \mathrm{kV}$ Primary Circuit Maintenance

$$
\begin{gathered}
N_{M E N T . E P 20 k V}=\frac{\sum_{i=1}^{16} R_{I} \cdot r_{i}}{\sum_{i=1}^{16} r_{i}}= \\
\frac{3 \cdot(2 \cdot 2)+2 \cdot(3 \cdot 3)+2 \cdot(4 \cdot 4)+4 \cdot(5 \cdot 5)+5 \cdot(6 \cdot 6)}{3 \cdot 2+2 \cdot 3+2 \cdot 4+4 \cdot 5+5 \cdot 6}=\frac{342}{70}=4,8
\end{gathered}
$$

\begin{tabular}{|c|c|c|c|}
\hline No. & RISK FACTOR & $\begin{array}{c}\text { RISK } \\
\text { LEVEL }\end{array}$ & $\begin{array}{l}\text { PROPOSED PREVENTIVE } \\
\text { MEASURES }\end{array}$ \\
\hline 1 & $\begin{array}{l}\text { Traveling by means of transport to the } \\
\text { workplace - road accident }\end{array}$ & 4 & $\begin{array}{l}\text { Preparation of instructions for } \\
\text { maneuvering and working } \\
\text { instructions for vehicle in the power } \\
\text { substation. Compliance with traffic } \\
\text { rules. }\end{array}$ \\
\hline 2 & $\begin{array}{l}\text { Hazard of explosion } \\
\text { transformers }\end{array}$ & 4 & $\begin{array}{l}\text { Wearing personal protective and } \\
\text { work equipment }\end{array}$ \\
\hline 3 & $\begin{array}{l}\text { Injury by the thermal effect of the } \\
\text { electric arc of service and repair } \\
\text { personnel when traveling on the } \\
\text { territory power substations of the work } \\
\text { load }\end{array}$ & 6 & $\begin{array}{l}\text { Wearing personal protective and } \\
\text { work equipment }\end{array}$ \\
\hline 4 & $\begin{array}{l}\text { Touching of accidentally live metal } \\
\text { parts under the conditions: } \\
\text { - damage to insulation from the metal } \\
\text { housing; } \\
\text { - failure of the protective connection }\end{array}$ & 6 & $\begin{array}{l}\text { Making connections to the ground } \\
\text { of all technical equipment. } \\
\text { Measuring touch voltages. } \\
\text { Compliance with the deadlines for } \\
\text { technical revisions }\end{array}$ \\
\hline 5 & $\begin{array}{l}\text { Adequate preparation and/or non- } \\
\text { compliance with mandatory steps and } \\
\text { measures to secure the work area }\end{array}$ & 5 & $\begin{array}{l}\text { Preparation of specific working } \\
\text { instructions regarding the } \\
\text { delimitation of the area work and the } \\
\text { execution and observance of the } \\
\text { work }\end{array}$ \\
\hline 6 & $\begin{array}{l}\text { Incorrect identification of the } \\
\text { installations in which they work, } \\
\text { wrong maneuvers when performing } \\
\text { functional tests }\end{array}$ & 6 & $\begin{array}{l}\text { The preparation of appropriate } \\
\text { working instructions and the } \\
\text { training of personnel on operating } \\
\text { conditions in the power substation }\end{array}$ \\
\hline
\end{tabular}

Table 8. Proposed measures sheet $-20 \mathrm{kV}$ Primary Circuit Maintenance 


\begin{tabular}{|c|l|c|l|}
\hline 7 & $\begin{array}{l}\text { Entering the work area unprepared for } \\
\text { work safety }\end{array}$ & 6 & $\begin{array}{l}\text { Compliance with the work and } \\
\text { safety instructions. Respect for } \\
\text { discipline in the workplace. }\end{array}$ \\
\hline 8 & $\begin{array}{l}\text { Incomplete work permit without } \\
\text { specifying all working area insurance } \\
\text { conditions }\end{array}$ & 6 & $\begin{array}{l}\text { Start work only under the work } \\
\text { authorization in which all conditions } \\
\text { for securing the working area shall } \\
\text { be specified }\end{array}$ \\
\hline 9 & $\begin{array}{l}\text { Exceeding the distances of materials to } \\
\text { the work area and during the works }\end{array}$ & 5 & $\begin{array}{l}\text { Withdrawal from service of } \\
\text { installations which are below the } \\
\text { limit of neighbourhood }\end{array}$ \\
\hline 10 & $\begin{array}{l}\text { Journeys, stationing in hazardous areas } \\
\text { outside the working area }\end{array}$ & 5 & $\begin{array}{l}\text { Following the internal instructions } \\
\text { for power substation travel }\end{array}$ \\
\hline 11 & $\begin{array}{l}\text { Not using the personal protective } \\
\text { equipment provided or use of personal } \\
\text { protective equipments non-certified }\end{array}$ & 5 & $\begin{array}{l}\text { Instructions on the use of the } \\
\text { personal protective equipment and } \\
\text { the certified personal protective } \\
\text { equipment }\end{array}$ \\
\hline
\end{tabular}

\subsubsection{Risk level assessment for activity: 20 kV Secondary Circuit Maintenance}

The team of revisions-repairs of equipments and secondary circuits and prophylaxis have as object of activity:

- revision;

- maintenance;

- repair of secondary protection and circuits;

- prophylaxis of power installations.

\section{Means of production:}

$20 \mathrm{kV}$ Power Substation:

- busbars;

- OHL switchgears;

- 110/20 kV AT switchgears;

- coupling switchgears (transversal / longitudinal / longo-transversal);

- compensating coil switchgears;

- busbar measuring switchgears;

- discharge switchgears, etc.

\section{Risk factors specific to the means of production:}

- electrical risk:

- direct contact (unprotected terminals, unprotected heating elements);

- indirect contact (housing, metal parts).

- mechanical risk:

- functional movements of technical equipments;

- displacements under the effect of propulsion.

- thermal risk:

- flames, explosion of molten metal particles.

\section{Work load:}

- protection checks:

- during the revisions, all the verifications provided by the technical books of protection are performed

- the monitoring of the protection system parameters is done from the $20 \mathrm{kV}$ control room. 
- measurements and verifications performed by the secondary equipments revisionsrepair team:

- at the internal service panels:

checking the electrical connections;

$>$ measurements at internal service cables;

$>$ measurements at internal service transformers;

$>$ checking switching devices and current transformers;

$>$ calibration of fuses on all circuits;

$>$ checking the ground connections.

- within the prophylaxis program of the primary equipment from the $20 \mathrm{kV}$ power substations, the following verification are performed:

- measurements and checks performed on voltage measuring transformers are:

$>$ measuring the insulation resistance of the windings;

$>$ measuring the tangent of the dielectric loss angle at the main insulation;

$>$ measuring the ohmic resistance of the windings;

$>$ raising the idling characteristic;

$>$ measuring the secondary load.

- measurements and checks performed on the current measuring transformers are:

$>$ measuring the insulation resistance of the windings;

$>$ measuring the tangent of the dielectric loss angle at the main insulation;

$>$ measuring the ohmic resistance of the windings;

$>$ raising the idling characteristic;

$>$ measuring the secondary load.

$>$ checking the polarity of the windings.

- measurements and checks performed on the circuit breakers are:

$>$ measuring the insulation resistance;

$>$ checking the contact resistance;

$>$ checking the ohmic resistance of the triggering and triggering coil;

$>$ low voltage operation of the control and automation installation;

$>$ checking the dielectric strength of the oil.

- measurements and checks performed at power cables are:

$>$ checking the continuity and identifying the phases;

$>$ measuring the insulation resistance.

Risk factors specific to the work load:

- psychic stress on decisions in circuit and scheme modification operations in relation to the consequences of mistakes in performing these operations;

- physical strain, forced working positions during check at the clamp strings.

\section{Performer:}

The team consists of electricians and a team leader ao foreman who are authorized in terms of OHS (groups I, II, III, IV, V).

\section{Risk factors specific to the performer:}

- wrong actions:

- touching the current paths during the high voltage tests;

- touching a point of the current paths;

- touching the terminals of devices, strings of clamps, relays;

- parking, hazardous movements.

- omissions: 
- non short circuiting of the secondary windings at the current transformers for carrying out works related to low voltage circuits;

- non short circuiting of the secondary terminals of the current transformers when opening the current circuits for mounting or dismounting the measuring devices;

- omission of the connection to the null busbar of the internal services of a conductor from the protection circuit to the own busbar;

- non use and/or non verification of personal protective equipments.

\section{Work environment:}

Revisions - repairs of primary equipments and secondary circuits.

\section{Risk factors specific to the work environment:}

- physical risk factors:

- lighting.

Table 9. Workplace assessment sheet $20 \mathrm{kV}$ Secondary Circuit Maintenance

\begin{tabular}{|c|c|c|c|c|c|c|}
\hline \multirow{2}{*}{\multicolumn{2}{|c|}{$\begin{array}{c}\text { NATIONAL POWER } \\
\text { SECTOR } \\
\text { RESPONSIBLE NATIONAL } \\
\text { COMPANY }\end{array}$}} & \multirow{3}{*}{$\begin{array}{c}\text { ASSESSMENT } \\
\text { SHEET } \\
\text { OF WORKPLACE }\end{array}$} & \multicolumn{4}{|c|}{$\begin{array}{c}\text { NUMBER OF EXPOSED } \\
\text { PERSONS }\end{array}$} \\
\hline & & & \multicolumn{4}{|c|}{$\begin{array}{c}\text { EXPOSURE TIME: } \\
\text { hours/shift }\end{array}$} \\
\hline $\begin{array}{r}20 \mathrm{kV} \text { SECOND } \\
\text { MAINTE }\end{array}$ & $\begin{array}{l}\text { RY CIRCUIT } \\
\text { ANCE }\end{array}$ & & \multicolumn{4}{|c|}{ ASSESSMENT TEAM: } \\
\hline $\begin{array}{c}\text { The composition } \\
\text { of the work } \\
\text { system }\end{array}$ & $\begin{array}{l}\text { Identified } \\
\text { risk factors }\end{array}$ & $\begin{array}{c}\text { CONCRETE } \\
\text { FORM } \\
\text { MANIFESTATIO } \\
\text { N OF RISK } \\
\text { FACTORS } \\
\end{array}$ & $\begin{array}{l}\text { Maximum } \\
\text { foreseeable } \\
\text { consequence }\end{array}$ & $\begin{array}{l}\text { Class of } \\
\text { severity }\end{array}$ & $\begin{array}{l}\text { Class of } \\
\text { probability }\end{array}$ & $\begin{array}{l}\text { Risk } \\
\text { level }\end{array}$ \\
\hline \multirow{5}{*}{$\begin{array}{c}\text { MEANS OF } \\
\text { PRODUCTION }\end{array}$} & \multirow{2}{*}{$\begin{array}{l}\text { Mechanical } \\
\text { risk factors: } \\
\text { - movement } \\
\text { under } \\
\text { dynamic } \\
\text { effect }\end{array}$} & $\begin{array}{l}\text { 1. Traveling by } \\
\text { means of transport to } \\
\text { the intervention area } \\
\text { - road accident }\end{array}$ & DEATH & 7 & 1 & 3 \\
\hline & & $\begin{array}{l}2 . \text { Explosions of } \\
\text { primary equipment, } \\
\text { during the } \\
\text { movement on the } 20 \\
\mathrm{kV} \text { substation } \\
\text { territory to perform } \\
\text { service attributions }\end{array}$ & DEATH & 7 & 1 & 3 \\
\hline & \multirow{2}{*}{$\begin{array}{l}\text { Electrical } \\
\text { risk factors } \\
\text { - direct } \\
\text { touch }\end{array}$} & $\begin{array}{ll}3 . & \text { Touching } \\
\text { unmarked terminals } \\
\text { and installations }\end{array}$ & DEATH & 7 & 1 & 3 \\
\hline & & $\begin{array}{l}\text { 4. Touching } 20 \mathrm{kV} \\
\text { busbar during } \\
\text { revisions or repairs }\end{array}$ & DEATH & 7 & 1 & 3 \\
\hline & $\begin{array}{l}\text { - indirect } \\
\text { touch }\end{array}$ & $\begin{array}{l}\text { 5. Touching of } \\
\text { accidentally } \\
\text { energized metal } \\
\text { parts under the } \\
\text { conditions of: } \\
\text { - insulation failure; } \\
\text { - damage to the } \\
\text { protective circuit by } \\
\text { grounding; }\end{array}$ & DEATH & 7 & 1 & 3 \\
\hline
\end{tabular}




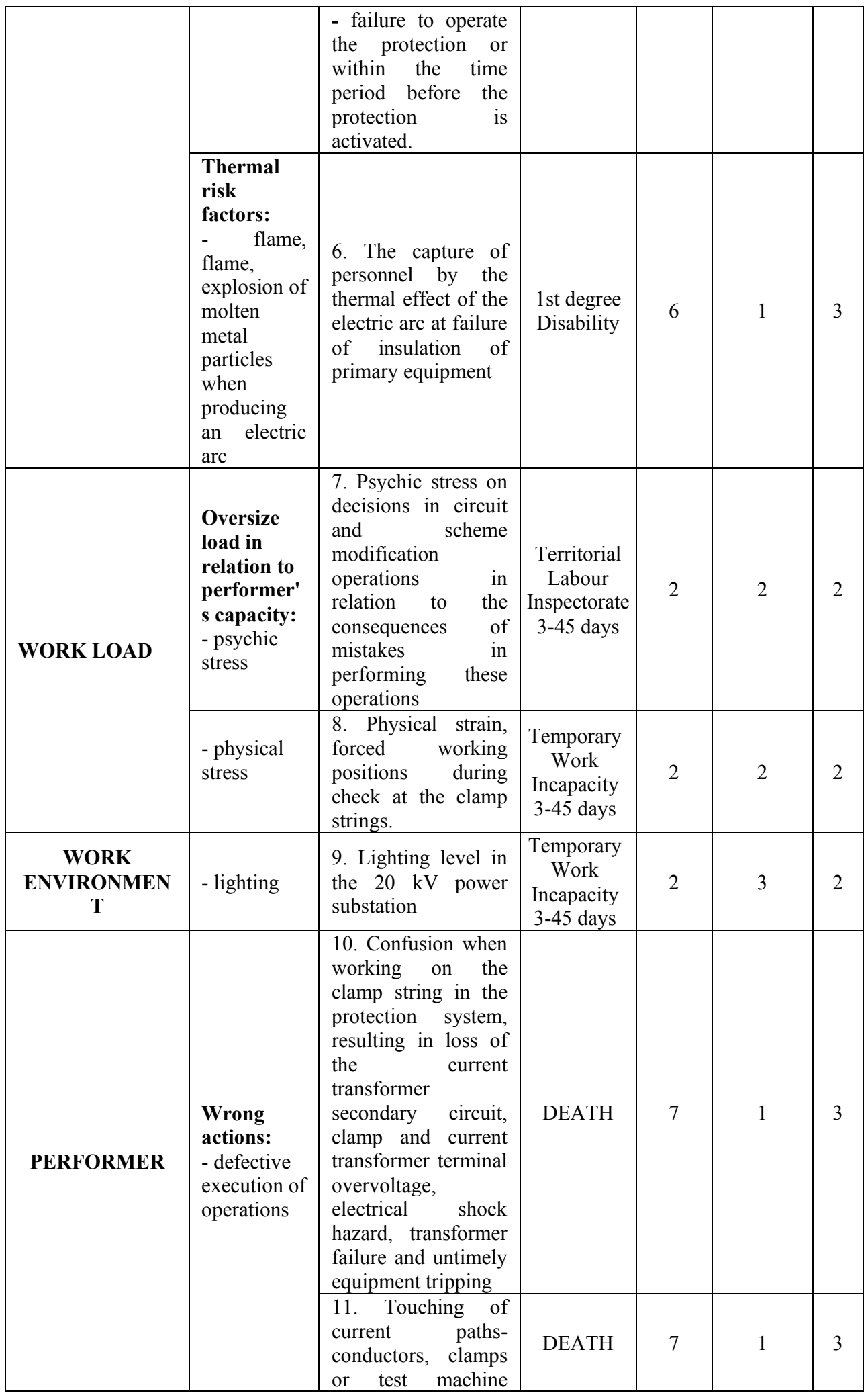




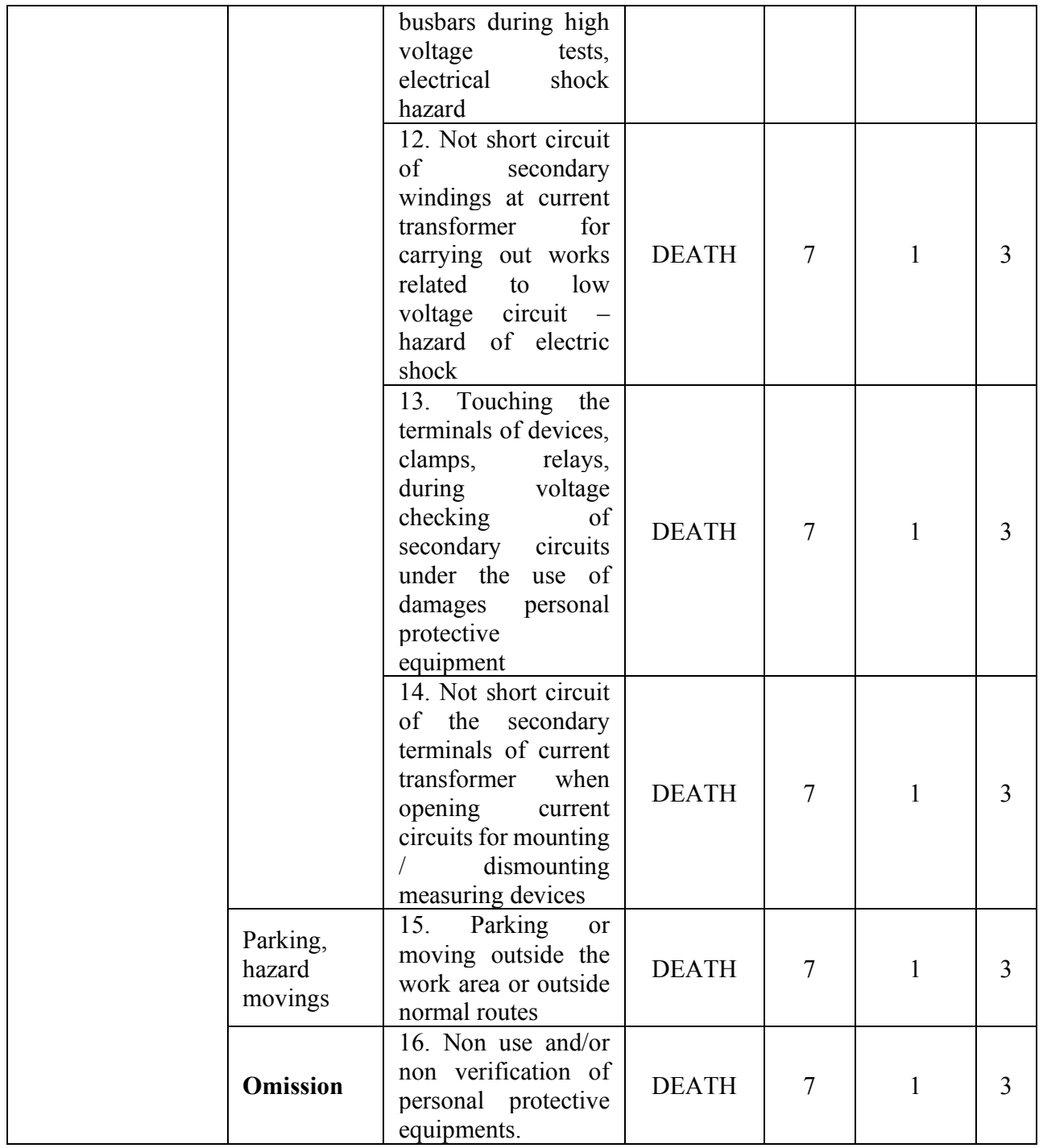

The global risk level at workplace: $20 \mathrm{kV}$ Secondary Circuit Maintenance

$$
N_{E P}=\frac{\sum_{i=1}^{17} R_{I} \cdot r_{i}}{\sum_{i=1}^{17} r_{i}}=\frac{13 \cdot(3 \cdot 3)+3 \cdot(2 \cdot 2)}{13 \cdot 3+3 \cdot 2}=\frac{129}{45}=2,87
$$

Table 10. Proposed measures sheet $-20 \mathrm{kV}$ Secondary Circuit Maintenance

\begin{tabular}{|c|c|c|c|}
\hline No. & RISK FACTOR & $\begin{array}{c}\text { RISK } \\
\text { LEVEL }\end{array}$ & $\begin{array}{c}\text { PROPOSED PREVENTIVE } \\
\text { MEASURES }\end{array}$ \\
\hline- & - & - & - \\
\hline
\end{tabular}

\subsection{Global risk level assessment of the $400 / 220 \mathrm{kV}$ power substation}

The risk levels, determined for each workplace in the $400 / 220 \mathrm{kV}$ power substation are generally the followings: 
Table 11. Workplace from $400 / 220 \mathrm{kV}$ power substation

\begin{tabular}{|c|l|c|}
\hline No. & \multicolumn{1}{|c|}{ WORKPLACE } & $\begin{array}{c}\text { LEVEL } \\
\text { RISK } \\
\left(\mathbf{N}_{\mathrm{rp}}\right)\end{array}$ \\
\hline 1 & $400 \mathrm{kV}$ and 220 kV OPERATIONAL SERVICE & $\mathbf{3 , 4}$ \\
\hline 2 & $20 \mathrm{kV}$ OPERATIONAL SERVICE & $\mathbf{3}$ \\
\hline 3 & $400 \mathrm{kV}$ and 220 kV PRIMARY CIRCUIT MAINTENANCE & $\mathbf{2 , 5 8}$ \\
\hline 4 & $20 \mathrm{kV}$ PRIMARY CIRCUIT MAINTENANCE & $\mathbf{4 , 8}$ \\
\hline 5 & $20 \mathrm{kV}$ SECONDARY CIRCUIT MAINTENANCE & $\mathbf{2 , 8 7}$ \\
\hline
\end{tabular}

The global risk level of the $400 / 220 \mathrm{kV}$ power substation is:

$$
\begin{gathered}
N_{r g}=\frac{\sum_{p=1}^{n} r_{p} \cdot N_{r p}}{\sum_{p=1}^{n} r_{p}}= \\
\frac{(3,4 \cdot 3,4)+(3 \cdot 3)+(2,58 \cdot 2,58)+(4,8 \cdot 4,8)+(2,87 \cdot 2,87)}{3,4+3+2,58+4,8+2,87}=\frac{49,48}{16,65}=2,97 \\
\begin{array}{c}
\mathbf{N}_{\text {rg-station }}=\mathbf{2 , 9 7} \\
\mathbf{N}_{\text {rg-power substation }}=\mathbf{2 , 9 7}
\end{array}
\end{gathered}
$$

\section{Conclusions}

The results of the assessment of risks of industrial injury and illness specific to activities carried out in a $400 / 220 \mathrm{kV}$ power substation. The assessment of the risks of injury and occupational disease was carried out for five activities that were highlighted at the station:

1) $400 \mathrm{kV}$ and $220 \mathrm{kV}$ Operational Service;

2) $20 \mathrm{kV}$ Operational Service;

3) $400 \mathrm{kV}$ and $220 \mathrm{kV}$ Primary Circuit Maintenance;

4) $20 \mathrm{kV}$ Primary Circuit Maintenance;

5) 20 kV Secondary Circuit Maintenance.

and are as follows (table 12).

Table 12. Risk factors / Risk levels per workplace / Global risk level of the Power Substation 400/220 $\mathrm{kV}$

\begin{tabular}{|c|c|c|c|c|}
\hline $\begin{array}{c}\mathbf{4 0 0} \mathbf{~ k V} \text { and } \\
\mathbf{2 2 0} \mathbf{~ k V} \\
\text { Operational } \\
\text { Service }\end{array}$ & $\begin{array}{c}\mathbf{2 0 ~ k V} \\
\text { Operational } \\
\text { Service }\end{array}$ & $\begin{array}{c}\mathbf{4 0 0} \mathbf{~ k V} \text { and } \\
\mathbf{2 2 0} \mathbf{~ k V} \\
\text { Primary } \\
\text { Circuit } \\
\text { Maintenance }\end{array}$ & $\begin{array}{c}\mathbf{2 0 ~ k V} \\
\text { Primary } \\
\text { Circuit } \\
\text { Maintenance }\end{array}$ & $\begin{array}{c}\mathbf{2 0 ~ k V} \\
\text { Secondary } \\
\text { Circuit } \\
\text { Maintenance }\end{array}$ \\
\hline $\begin{array}{c}\text { number risk } \\
\text { factor } \rightarrow \text { risk } \\
\text { level }\end{array}$ & $\begin{array}{c}\text { number risk } \\
\text { factor } \rightarrow \text { risk } \\
\text { level }\end{array}$ & $\begin{array}{c}\text { number risk } \\
\text { factor } \rightarrow \text { risk } \\
\text { level }\end{array}$ & $\begin{array}{c}\text { number risk } \\
\text { factor } \rightarrow \text { risk } \\
\text { level }\end{array}$ & $\begin{array}{c}\text { number risk } \\
\text { factor } \rightarrow \text { risk } \\
\text { level }\end{array}$ \\
\hline $1 \rightarrow 1$ & $1 \rightarrow 3$ & $1 \rightarrow 3$ & $1 \rightarrow 4$ & $1 \rightarrow 3$ \\
\hline $2 \rightarrow 4$ & $2 \rightarrow 3$ & $2 \rightarrow 2$ & $2 \rightarrow 3$ & $2 \rightarrow 3$ \\
\hline $3 \rightarrow 4$ & $3 \rightarrow 3$ & $3 \rightarrow 3$ & $3 \rightarrow 2$ & $3 \rightarrow 3$ \\
\hline $4 \rightarrow 3$ & $4 \rightarrow 3$ & $4 \rightarrow 4$ & $4 \rightarrow 4$ & $4 \rightarrow 3$ \\
\hline $5 \rightarrow 4$ & $5 \rightarrow 3$ & $5 \rightarrow 3$ & $5 \rightarrow 6$ & $5 \rightarrow 3$ \\
\hline $6 \rightarrow 3$ & $6 \rightarrow 3$ & $6 \rightarrow 2$ & $6 \rightarrow 6$ & $6 \rightarrow 3$ \\
\hline
\end{tabular}




\begin{tabular}{|c|c|c|c|c|}
\hline \multirow[t]{10}{*}{$7 \rightarrow 1$} & $7 \rightarrow 3$ & $7 \rightarrow 2$ & $7 \rightarrow 5$ & $7 \rightarrow 2$ \\
\hline & $8 \rightarrow 3$ & $8 \rightarrow 3$ & $8 \rightarrow 3$ & $8 \rightarrow 2$ \\
\hline & $9 \rightarrow 3$ & $9 \rightarrow 3$ & $9 \rightarrow 2$ & $9 \rightarrow 2$ \\
\hline & $10 \rightarrow 3$ & $10 \rightarrow 4$ & $10 \rightarrow 6$ & $10 \rightarrow 3$ \\
\hline & \multirow[t]{6}{*}{$11 \rightarrow 3$} & $11 \rightarrow 3$ & $11 \rightarrow 6$ & $11 \rightarrow 3$ \\
\hline & & $12 \rightarrow 3$ & $12 \rightarrow 6$ & $12 \rightarrow 3$ \\
\hline & & $13 \rightarrow 1$ & $13 \rightarrow 5$ & $13 \rightarrow 3$ \\
\hline & & \multirow[t]{3}{*}{$14 \rightarrow 3$} & $14 \rightarrow 5$ & $14 \rightarrow 3$ \\
\hline & & & $15 \rightarrow 2$ & $15 \rightarrow 3$ \\
\hline & & & $16 \rightarrow 5$ & $16 \rightarrow 3$ \\
\hline $\begin{array}{c}\text { Work } \\
\text { environment } \\
14 \% \\
\end{array}$ & $\begin{array}{c}\text { Work } \\
\text { environment } \\
9 \% \\
\end{array}$ & $\begin{array}{c}\text { Work } \\
\text { environment } \\
7 \% \\
\end{array}$ & $\begin{array}{c}\text { Work } \\
\text { environment } \\
6 \% \\
\end{array}$ & $\begin{array}{c}\text { Work } \\
\text { environment } \\
6 \% \\
\end{array}$ \\
\hline $\begin{array}{c}\text { Performer } \\
29 \% \\
\end{array}$ & $\begin{array}{c}\text { Performer } \\
36 \% \\
\end{array}$ & $\begin{array}{c}\text { Performer } \\
50 \% \\
\end{array}$ & $\begin{array}{c}\text { Performer } \\
43 \% \\
\end{array}$ & $\begin{array}{c}\text { Performer } \\
43 \%\end{array}$ \\
\hline \multirow[t]{2}{*}{$\begin{array}{c}\text { Mean of } \\
\text { Production } \\
57 \% \\
\end{array}$} & $\begin{array}{c}\text { Mean of } \\
\text { Production } \\
55 \% \\
\end{array}$ & $\begin{array}{c}\text { Mean of } \\
\text { Production } \\
29 \% \\
\end{array}$ & $\begin{array}{c}\text { Mean of } \\
\text { Production } \\
38 \% \\
\end{array}$ & $\begin{array}{c}\text { Mean of } \\
\text { Production } \\
8 \% \\
\end{array}$ \\
\hline & & $\begin{array}{c}\text { Work load } \\
14 \% \\
\end{array}$ & $\begin{array}{c}\text { Work load } \\
13 \% \\
\end{array}$ & $\begin{array}{c}\text { Work load } \\
13 \% \\
\end{array}$ \\
\hline $\begin{array}{c}\text { Risk level } \\
\mathbf{3 , 4} \\
\text { Unacceptable }\end{array}$ & $\begin{array}{c}\text { Risk level } \\
3 \\
\text { Low }\end{array}$ & $\begin{array}{c}\text { Risk level } \\
2,58 \\
\text { Very Low }\end{array}$ & $\begin{array}{c}\text { Nivel risk } \\
4,8 \\
\text { Unacceptable }\end{array}$ & $\begin{array}{c}\text { Nivel risk } \\
2,87 \\
\text { Very low }\end{array}$ \\
\hline
\end{tabular}

These risk factors must be the focus of those who coordinate the activities of the 400/220 $\mathrm{kV}$ power station, as they can always be manifested in an event that can result in human casualties. The conclusion is that those who lead and coordinate the work are not influenced by the global value of the level of risk (which is a weighted average of the risk levels and risk factors identified), but take account of these risk factors with the maximum possible consequence of DEATH for which existing preventive measures must be maintained and the adoption of additional preventive measures. Given the risk factors identified for each assessed activity, specific to the elements of the work system and taking into account the level of risk corresponding to each risk factor, a number of preventive measures have been proposed. After the analysis, it was concluded that the $400 / 220 \mathrm{kV}$ power substation should enter full retechnologization, for the following reasons:

- the age of apparatus and equipments in the primary circuits of the $400 \mathrm{kV}, 220 \mathrm{kV}$ and $20 \mathrm{kV}$ power substations,

- the age of apparatus in the secondary circuits of the $400 \mathrm{kV}, 220 \mathrm{kV}$ and $20 \mathrm{kV}$ power substations.

Due to these very old apparatus and equipment, the hazard of incidents is very great, which would endanger the good functioning of the National Power Grid. The risk of injury and occupational disease is particularly high in the $20 \mathrm{kV}$ power substation, which is also a reason for the power substation to go into full retechnologization.

\section{References}

1. National Research and Development Institute of Occupational Safety Alexandru Darabont - Method for risk assessment in term of OHS (2021)

2. SR OHSAS 45001:2018, Occupational Health and Safety Management Systems - Requirements with guidance for use, (Romanian Standardization Association - ASRO) (2018)

3. https://www.sri.ro/upload/Brosura\%20IC\%20ENG.pdf, [Accessed 13.03.2021] 
4. N.D. Fita, S.M. Radu, D. Pasculescu, Ensuring, controlling and stability of energy security in the context of increasing industrial and national security - Academic compendium, (UPH, Petrosani, 2021)

5. N.D. Fita, Identifying vulnerabilities of critical infrastructures from national power grid in the context of increasing enegy security (UPH, Petrosani, 2019)

6. N.D. Fita, R. Moraru, G. Babut, D. Pasculescu, L. Pana, M. Badica, N. Visan, Electrical safety of critical infrastructures and personnel within the national power grid (UPH, Petrosani, 2019)

7. R.I. Moraru, G.B. Babut, Professional risk assessment: Mentor for practical applications and projects (UPH, Petrosani (2013)

8. Romanian Parliament 319/2006 Occupational Health and Safety Law (2021)

9. L. Pana, J. Grabara, D. Pasculescu, V.M. Pasculescu, R.I. Moraru, Polish Journal of Management Studies, 18 (2), 12 (2018)

10. D. Pasculescu, L. Pana, V.M. Pasculescu, F. Deliu, Mining of Mineral Deposits, 13 (2), 16 (2019)

11. A.D. Handra, F.G. Popescu, D. Pasculescu, Utilizarea energiei electrice - lucrari de laborator (UPH, Petrosani, 2020)

12. F.G. Popescu, D. Pasculescu, V.M. Pasculescu, Modern methods for analysis and reduction of current and voltage harmonics (LAP LAMBERT Academic Publishing, 2020)

13. F. G. Popescu, D. Pasculescu, M. D. Marcu, V. M. Pasculescu, Mining of Mineral Deposits, 14 (4), 7 (2020)

14. F. G. Popescu, D. Pasculescu, M. Marcu, T. Niculescu, A. D. Handra, Annals of University of Petrosani, Electrical Engineering, 21, 8 (2019)

15. M.D. Marcu, L. Pana, F.G. Popescu, R. Slusariuc, SGEM'14, Evaluation the losses power and electrical energy on the basis of the relative load curves, by reference to the basic sizes, (Albena Bulgaria, 2014)

16. N.D. Fita, C. Barb, D. Pasculescu, L. Pana, MSE'19, The description and evaluation of technical incident risk on the National Power Grid in the context of power safety growth, (Sibiu, Romania, 2019)

17. T. Niculescu, V. Arad, M. Marcu, S. Arad, F. G. Popescu, Mining of Mineral Deposits, 14 (3), 9 (2020)

18. G. Buica, A.E. Antonov, C. Beiu, D. Pasculescu, R. Dobra, Supplement of Quality-Access to Success, 18 (S1), 6 (2017) 